\title{
AFDN Gene
}

National Cancer Institute

\section{Source}

National Cancer Institute. AFDN Gene. NCI Thesaurus. Code C24604.

This gene is involved in cell adhesion and cytoskeletal modeling. 